Ветеринарная микробиология

\title{
БИОХИМИЧЕСКИЕ, АНТИГЕННЫЕ И ПРОТЕОМИЧЕСКИЕ СВОЙСТВА РОССИЙСКИХ И БЕЛОРУССКИХ ИЗОЛЯТОВ ВОЗБУДИТЕЛЯ ИНФЕКЦИОННОГО РИНИТА КУР Avibacterium paragallinarum (Biberstein and White 1969) Blackall et al. 2005
}

\author{
А.В. ПОТЕХИН, Н.Б. ШАДРОВА, О.В. ПРУНТОВА, В.С. РУСАЛЕЕВ, \\ В.А. ЕВГРАФОВА
}

Инфекционный ринит кур (гемофилез кур) - заболевание, зарегистрированное во многих странах мира. В Российской Федерации отсутствует информация о степени его распространения в птицеводческих хозяйствах, равно как и о серотиповом разнообразии возбудителя, циркулирующего в стране. В настоящей работе впервые приведены биохимические характеристики и определено антигенное родство новых изолятов Avibacterim paragallinarum, полученных от кур с респираторной патологией из ряда хозяйств, а также представлены результаты создания подраздела базы данных масс-спектров исследуемых микроорганизмов, используемых в качестве референтных при идентификации и белковом профилировании штаммов и изолятов возбудителя инфекционного ринита кур. Цель работы - определение биохимических и антигенных свойств изолятов Avibacterium paragallinarum, выявленных в Российской Федерации и Республике Беларусь, и получение специфичных для представителей вида масс-спектров с их последующим анализом и использованием для идентификации и внутривидовой дифференциаци. Референтный штамм $A$. paragallinarum № 29545 АТСС (серотип A1) был получен из коллекции штаммов микроорганизмов ФГБУ Федеральный центр охраны здоровья животных (ФГБУ ВНИИЗЖ). В исследовании использовали 13 изолятов бактерий $A$. paragallinarum, выделенных из патологического материала (содержимого подглазничных синусов и конъюнктивального мешка, экссудата из носовой полости, ткани легкого) от кур с респираторной патологией при обследовании птицеводческих хозяйств в 2015 году. Изоляты высевали на агар Columbia, содержащий $5 \%$ дефибринированной крови барана, с посевом штамма Staphylococcus epidermidis в качестве баккормилки. Чистые культуры возбудителя выращивали на сывороточном агаре, содержащем 20 мкг/см 3 НАДФ и $5 \%$ сыворотки крови лошади. Бактерии культивировали 24-72 ч при $37{ }^{\circ} \mathrm{C}$ в условиях повышенного содержания углекислого газа. Двустороннее антигенное родство референтного штамма АТСС № 29545 и изолятов $A$. paragallinarum определяли в реакции агглютинации на стекле. Гемагглютинирующую активность оценивали в реакции торможения гемагглютинации. Гомогенность серогруппы исследуемых изолятов подтверждали методом ПЦР. Присутствие амплифицированных фрагментов ДНК размером 800 п.н. указывало на наличие генома $A$. paragallinarum серогрупाы A, 1000-1100 п.н. - серогруппы В, 1500-1600 п.н. - серогруппы С. Идентификацию бактерий A. paragallinarum осуществляли на масс-спектрометре MALDI Autoflex III Biotyper («Bruker Daltonik GmbH», Германия). Запись, обработку и анализ полученных масс-спектров проводили в программе FlexControl 3.4 («Bruker Daltonik GmbH», Германия) в соответствии с MALDIBiotyper 2.0. UserManual, Version 2.0 SR1 (Germany, 2008). При определении биохимических свойств было установлено, что изоляты A. paragallinarum представляют собой неоднородную группу. Зависимость роста изолятов A. paragallinarum от присутствия в питательной среде сыворотки крови была абсолютной. Сахаролитическая активность изолятов различалась. Все изоляты и референтный штамм ферментировали сахарозу и глюкозу, но не трегалозу, лактозу и галактозу. Вариабельность признака наблюдали в отношении маннита и маннозы. По антигенным свойствам все исследуемые изоляты принадлежали к одной серогруппе В, что также подтвердили методом ПЦР в реальном времени. При изучении протеомических свойств штаммов изолятов A. paragallinarum были определены характерные пики $\mathrm{m} / \mathrm{z}$ 4768-4770 и 5347-5349 масс-спектров, аналогичные таковым для референтного штамма A. paragallinarum АТCC № 29545. Масс-спектры белковых профилей изучаемых изолятов и штаммов включены в базу данных масс-спектрометра MALDI Autoflex III Biotyper, что позволило повысить степень достоверности видовой идентификации A. paragallinarum. На основании изученных биохимических, антигенных и протеомных характеристик три изолята депонированы в Государственную коллекцию штаммов микроорганизмов ФГБУ Федеральный центр охраны здоровья животных как $A$. paragallinarum штамм № 1818, A. paragallinarum штамм № 5111 и $A$. paragallinarum штамм № 1116.

Ключевые слова: штаммы, изоляты, Avibacterim paragallinarum, идентификация, биохимические свойства, антигенные свойства, протеомические свойства, масс-спектрометрия, реакция агглютинации, реакция торможения гемагглютинации. 
Инфекционный ринит кур (возбудитель Avibacterium paragallinarum, сем. Pasteurellaceae; грамотрицательная бактерия, которую ранее классифицировали как Haemophilus paragallinarum) - заболевание, широко распространенное в промышленных птицеводческих хозяйствах Аргентины, Африки, Австралии, Бангладеш, Бразилии, Болгарии, Египта, Индонезии, Индии, Китая, Мексики, Малайзии, США (штаты Калифорния, Орегон и Алабама), Таиланда, Японии (1-4). Оно характеризуется катаральным воспалением слизистых оболочек носовой полости, воздухоносных пазух и конъюнктивы, подкожным отеком головы, изредка - пневмонией (5-7). Инфекционный ринит наносит значительный экономический ущерб птицеводству из-за задержки роста у цыплят и потери яйценоскости у кур (до 40 \%) (7). Падеж молодняка кур может достигать $10 \%$ (1). Степень распространения этого заболевания в птицеводческих хозяйствах Российской Федерации неизвестна, как и серотиповое разнообразие возбудителя, поскольку лабораторная диагностика инфекционного ринита кур не регламентирована соответствующими документами.

Традиционно возбудителя болезни идентифицируют по ростовым, морфологическим и биохимическим свойствам. Появление в лабораторной практике масс-спектрометрических методов, основанных на анализе белковой или липидной фракций микробной клетки, повысило возможности ветеринарных специалистов по идентификации бактерий. Протеомные методы определения видовой принадлежности микроорганизмов не уступают генотипическим по многим параметрам (чувствительность, разрешающая способность), а по стоимости расходных материалов, скорости анализа и отсутствию влияния неспецифичной ДНК на результат имеют явное преимущество. Белковое профилирование методом масс-спектрометрии представляет собой мощный аналитический инструмент как в фундаментальных областях, так и в клинической практике $(8,9)$. Применение протеомных методов для идентификации и исследования свойств изолятов A. paragallinarum - экономически значимого, но пока что недостаточно изученного патогена со сложной антигенной структурой позволяет получить новые знания о его биологии, которые могут быть использованы для решения практических задач ветеринарии.

MALDI-TOF (matrix-assisted laser desorption/ionization, времяпролетная масс-спектрометрия с матрично-активированной лазерной десорбцией/ионизацией) - метод идентификации микроорганизмов, который основан на определении набора белков, уникального для каждого вида. Он заключается в высвобождении и ионизации мембранных белков с помощью лазерного излучения в присутствии вспомогательного вещества (матрицы) и последующем разделении ионов во времяпролетном массанализаторе $(10,11)$. Однако в идентификационной базе MALDI BioTyper («Bruker Daltonik GmbH», Германия) данные о белковых масс-спектрах бактерий вида A. paragallinarum ранее отсутствовали, вследствие чего использовать этот метод для идентификации изолятов A. paragallinarum не представлялось возможным.

В настоящей работе впервые представлены результаты создания дополнительного раздела базы данных масс-спектров микроорганизмов на уровне вида $A$. paragallinarum для использования в качестве референтных при идентификации и белковом профилировании изолятов и штаммов возбудителя инфекционного ринита кур, а также биохимические характеристики и сведения об антигенном родстве изолятов A. paragallinarum, выделенных нами ранее в птицеводческих хозяйствах Российской Федерации 
и Республики Беларусь от кур с респираторной патологией.

Цель работы - определение биохимических и антигенных свойств изолятов Avibacterium paragallinarum из России и Белоруссии и получение специфичных для представителей вида масс-спектров с последующим их анализом и использованием для идентификации и внутривидовой дифференциации.

Методика. Референтный штамм A. paragallinarum № 29545 ATCC (серотип A1) получили из Государственной коллекции штаммов микроорганизмов ФГБУ Федеральный центр охраны здоровья животных (ФГБУ ВНИИЗЖ). В исследовании использовали 13 изолятов бактерий A. paragallinarum, выделенных из патологического материала (содержимого подглазничных синусов и конъюнктивального мешка, экссудата из носовой полости, ткани легкого) от кур с респираторной патологией из птицеводческих хозяйств Российской Федерации (Владимирская, Костромская, Московская, Оренбургская, Ярославская, Ульяновская области, Республика Мордовия, Республика Татарстан) и Республики Беларусь в 2015 году.

Бактерии культивировали на следующих питательных средах с ростостимулирующими добавками: колумбийский бульон и агар (Columbia Columbia Broth, Columbia Agar, «Becton, Dickinson and Co.», США), агар Мюллера-Хинтона («HiMedia Laboratories Pvt. Ltd», Индия), сыворотка лошадиная нормальная для культивирования микроорганизмов (АО НПО «Микроген», Россия), НАДФ («Bontac Bio-Engineering Co., Ltd», Китай), среды Гисса (НПО «Питательные среды», Россия).

Выделение изолятов $A$. paragallinarum из патологического материала осуществляли посредством высева на агар Columbia, содержащий $5 \%$ дефибринированной крови барана, с дополнительным посевом штамма Staphylococcus epidermidis в качестве баккормилки. Чистые культуры воз-

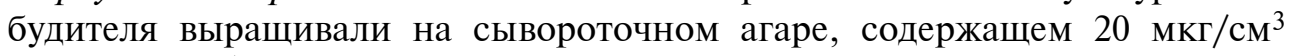
НАДФ и $5 \%$ сыворотки крови лошади. Бактерии культивировали в течение 24-72 ч при $37{ }^{\circ} \mathrm{C}$ и повышенном содержании $\mathrm{CO}_{2}$.

Морфологию бактерий изучали методом световой микроскопии мазков, окрашенных по Граму (микроскоп EclipseNi-U, «Nikon Corporation», Япония, увеличение ×1000) (12). Капсулы у бактерий идентивицировали в мазках, окрашенных по Гинсу (12). Биохимические свойства изолятов определяли при помощи коммерческого набора APINH («bioMerieux $\mathrm{SA}$, Франция) и посевом на среды Гисса с моноуглеводами (глюкоза, сахароза, лактоза, маннит, манноза, трегалоза, галактоза). Продукцию каталазы оценивали на предметном стекле с $3 \%$ раствором $\mathrm{H}_{2} \mathrm{O}_{2}$. Оксидазную активность измеряли при помощи коммерческого набора API NH в соответствии с инструкцией производителя («bioMerieux SA», Франция).

Двустороннее антигенное родство между изолятами A. paragallinarum и антигенные свойства референтного штамма АТСС № 29545 определяли в реакции агглютинации (РА) на стекле по методике, предложенной L.A. Page (13). Гемагглютинирующую активность оценивали в реакции торможения гемагглютинации (РТГА) по методике, описанной P.J. Blackall с соавт. (14). Степень двустороннего антигенного родства (R) изолятов A. paragallinarum рассчитывали по формуле I. Archetti и F.L. Horsfall (15) и выражали в процентах. Значение R 70 \% при 3-кратной повторности титрования рассматривали как подтверждение статистически достоверного родстве исследуемых изолятов (15).

Гомогенность серогруппы изолятов A. paragallinarum подтверждали методом мультиплексной полимеразной цепной реакции в реальном вре- 
мени (ПЦР-PB, qPCR) (микрочиповый амплификатор нуклеиновых кислот АриаДНА ${ }^{\circledR}$, ООО «Люмэкс», Россия). Бактериальную ДНК получали при помощи набора для выделения нуклеиновых кислот (ООО «Биоком», Россия). Термоциклирование образцов проводили в режиме: 10 мин при $95{ }^{\circ} \mathrm{C}$ (1 цикл); при 30 с при $95^{\circ} \mathrm{C}, 30$ с при $56{ }^{\circ} \mathrm{C}, 90$ с при $32{ }^{\circ} \mathrm{C}(35$ циклов). В работе использовали четыре праймера, предложенные R. Sakamoto c соавт. (16) (ООО «Бигль», г. Санкт-Петербург): прямой праймер (общий для амплификации генома у трех серогрупп A. paragallinarum) и три обратных праймера, специфичных для определенной серогруппы.

Продукты амплификации анализировали методом электрофореза в $1,7 \%$ агарозном геле с бромидом этидия при напряжении 15 В/см длины геля в течение 45 мин (ООО «Люмэкс», Россия). Результаты электрофореза учитывали на трансиллюминаторе TCP-26.LMX («Vilber Lourmat», Франция) в ультрафиолетовом свете $(\lambda=254$ нм). Амплифицированные фрагменты ДНК выявлялись в виде светящихся оранжевых полос.

Результаты считали положительными при обнаружении ампликонов 800 п.н., 1000-1100 п.н. и 1500-1600 п.н. Выявление фрагментов длиной 800 п.н. свидетельствовало о наличии генома A. paragallinarum cepoгруппы А, 1000-1100 п.н. - серогруппы В, 1500-1600 п.н. - серогруппы С. Результаты считали отрицательными, если указанные амплифицированные фрагменты ДНК не выявлялись или их размер не соответствовал приведенным величинам $(16,17)$.

Идентификацию бактерий A. paragallinarum осуществляли на массспектрометре MALDI Autoflex III Biotyper («Bruker Daltonik GmbH», Германия). Применяли метод прямого нанесения, при котором единичные колонии свежей культуры вносили в лунки металлического планшета, используя стерильную петлю, сверху помещали матрицу в объеме 1 мкл. В качестве матрицы использовали насыщенный раствор CHCA ( $\alpha$-циано-4гидроксикоричная кислота) в 50 \% водном ацетонитриле, содержащем 2,5 \% трифторуксусной кислоты. Прибор калибровали перед каждым экспериментом, в качестве калибранта использовали Bruker Bacterial Standard («Bruker Daltonik GmbH», Германия). Масс-спектрометрический анализ культур A. paragallinarum осуществляли с применением линейного режима лазера при частоте 50 Гц. Параметры анализа оптимизировали для диапазона масс m/z (масса/заряд) от 2000 до 20000 Да, записывали спектр, полученный в результате суммирования 20 одиночных спектров. Запись и анализ полученных масс-спектров проводили в программе FlexControl 3.4 и FlexAnalysis 3.0 («Bruker Daltonik GmbH», Германия) в соответствии с MALDIBiotyper 2.0. UserManual, Version 2.0 SR1 (Germany, 2008).

Статистическую обработку полученных масс-спектров проводили с использованием программы Biotyper 3.0 RTC («Bruker Daltonik GmbH», Германия). Достоверность результатов при идентификации микроорганизмов оценивали по полученным значениям Score, сравнивая их с данными масс-спектров референсной библиотеки Biotyper 3.0. Результат идентификации микроорганизмов при Score $<1,7$ рассматривали как недостоверный. При анализе степени двустороннего антигенного родства $(\mathrm{R}, \%)$ в повторностях рассчитывали средние $(M)$ и стандартные ошибки средних ( \pm SEM).

Результаты. На кровяном агаре с «бактерией-кормилкой» (источник V-фактора роста) через 24 ч культивирования изоляты A. paragallinarum, полученные от кур с респираторной патологией, имели вид мелких (0,1-0,5 мм) сателлитных колоний в зоне 0,5-1,5 см от штриха культуры 
S. epidermidis. По мере удаления от питающей культуры размер колоний уменьшался вплоть до полного исчезновения роста. Сателлитные колонии были серо-белого цвета, имели гладкую выпуклую поверхность без зоны гемолиза и округлую форму с ровными краями.

При сравнении изолятов с референтным штаммом A. paragallinarum № 29545 АТСС учитывали способность культур расти на питательных средах без сыворотки крови, при повышенном содержании углекислого газа в атмосфере, расщеплять углеводы, продуцировать различные ферменты и метаболиты. Полученные результаты позволили заключить, что изоляты и референтный штамм возбудителя инфекционного ринита кур по ростовым свойствам и ферментативной активности представляют собой неоднородную группу (табл. 1).

1. Ростовые и биохимические свойства референтного штамма Avibacterium paragallinarum № 29545 АТСС и изолятов A. paragallinarum, полученных от кур с респираторной патологией

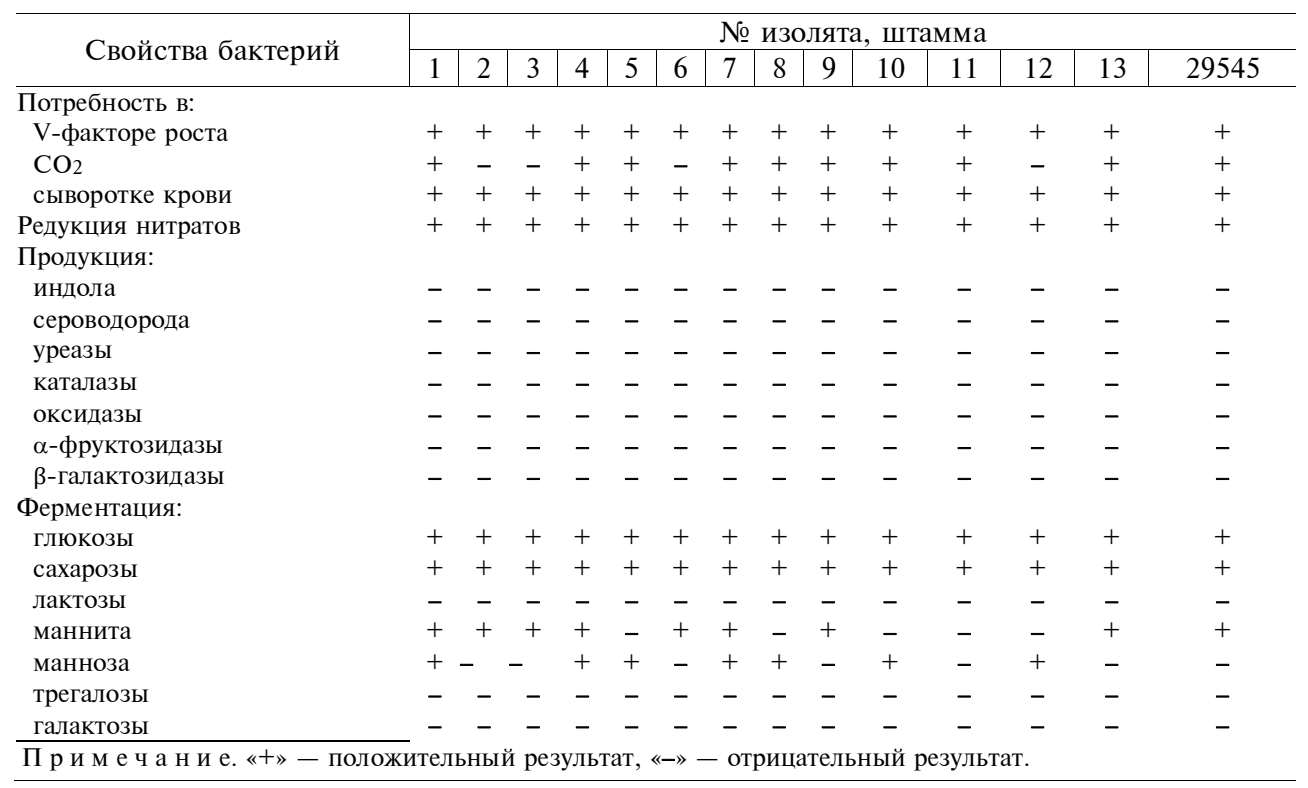

В наших опытах штамм A. paragallinarum и все изоляты были НАДзависимыми, хотя имеются сообщения и о выделении НАД-независимых изолятов возбудителя (18). Для изолятов A. paragallinarum были характерны способность редуцировать нитраты в нитриты и отсутствие продукции оксидазы, $\alpha$-фруктозидазы, $\beta$-галактозидазы, индола, сероводорода, уреазы, каталазы. Зависимость роста изолятов и штамма от наличия в питательной среде сыворотки крови оказалась абсолютной. Получить рост A. paragallinarum на среде без сыворотки не удалось даже при оптимальном содержании V-фактора. Согласно утверждению ряда зарубежных авторов, рост A. paragallinarum возможен только при наличии повышенного содержания углекислого газа в атмосфере (18-20). Однако в наших опытах подобную зависимость проявили только 9 из 13 изолятов (№№ 1, 4, 5, 7, 8, 9, 10 и 11). Морфология и размер колоний у четырех изолятов, выращенных в обычной воздушной атмосфере, ничем не отличались от таковых у колоний в условиях повышенного содержания $\mathrm{CO}_{2}$. Сахаролитическая активность у A. paragallinarum также была неодинаковой. Все изоляты и референтный штамм ферментировали сахарозу и глюкозу, но не трегалозу, 
2. Антигенное родство ( $\mathrm{R}, \%)$ изолятов Avibacterium paragallinarum, полученные от кур с респираторной патологией, в реакции торможения гемагглютинации $(n=3, M \pm \mathrm{SEM})$

\begin{tabular}{|c|c|c|c|c|c|c|c|c|c|c|c|c|c|}
\hline \multirow{2}{*}{ № изолята } & \multicolumn{13}{|c|}{ Сыворотка, специфичная к антигену } \\
\hline & 1 & 2 & 3 & 4 & 5 & 6 & 7 & 8 & 9 & 10 & 11 & 12 & 13 \\
\hline 1 & 100 & 100 & $96,8 \pm 2,0$ & $86,8 \pm 2,0$ & $92,4 \pm 1,2$ & $86,4 \pm 2,6$ & $88,8 \pm 2,3$ & $92,4 \pm 2,3$ & $96,7 \pm 1,2$ & $96,2 \pm 0,2$ & $87,7 \pm 2,2$ & $97,7 \pm 1,1$ & $90,4 \pm 0,6$ \\
\hline 2 & $92,6 \pm 2,0$ & 100 & $94,6 \pm 0,8$ & $92,6 \pm 1,8$ & $98,2 \pm 0,4$ & $94,6 \pm 3,0$ & $86,6 \pm 2,6$ & 100 & $90,2 \pm 0,9$ & $82,4 \pm 1,8$ & $85,2 \pm 0,8$ & $89,4 \pm 1,0$ & $89,1 \pm 0,9$ \\
\hline 3 & $98,6 \pm 1,2$ & $96,4 \pm 1,2$ & 100 & 100 & $84,2 \pm 1,0$ & $94,8 \pm 0,5$ & $90,4 \pm 1,2$ & $98,4 \pm 1,2$ & $86,2 \pm 1,5$ & $84,8 \pm 1,2$ & $86,6 \pm 2,0$ & $87,9 \pm 0,4$ & $86,4 \pm 1,6$ \\
\hline 4 & 100 & $94,8 \pm 2,0$ & $95,2 \pm 3,0$ & 100 & $94,2 \pm 1,6$ & $88,4 \pm 2,8$ & $96,8 \pm 0,5$ & 100 & $94,6 \pm 1,2$ & $98,8 \pm 0,1$ & $88,0 \pm 2,0$ & $91,6 \pm 0,4$ & 100 \\
\hline 5 & $87,6 \pm 2,0$ & $93,0 \pm 2,0$ & $87,4 \pm 2,8$ & $97,8 \pm 2,0$ & 100 & $98,2 \pm 1,2$ & $84,6 \pm 2,0$ & $90,2 \pm 2,2$ & $97,2 \pm 1,0$ & 100 & $79,9 \pm 1,9$ & $92,5 \pm 0,8$ & $96,2 \pm 0,8$ \\
\hline 6 & $90,2 \pm 1,3$ & 100 & $79,6 \pm 2,1$ & $96,2 \pm 2,0$ & $86,2 \pm 1,0$ & 100 & $88,2 \pm 2,2$ & $92,6 \pm 1,8$ & 100 & $96,4 \pm 0,8$ & $89,4 \pm 1,3$ & $92,7 \pm 0,6$ & $94,3 \pm 0,2$ \\
\hline 7 & $94,6 \pm 2,1$ & $96,6 \pm 2,4$ & $91,3 \pm 3,4$ & 100 & $96,8 \pm 0,5$ & 100 & 100 & $98,2 \pm 1,0$ & $99,3 \pm 0,5$ & $86,8 \pm 1,8$ & $94,4 \pm 1,0$ & $94,8 \pm 0,2$ & $82,3 \pm 0,3$ \\
\hline 8 & $88,2 \pm 0,6$ & 100 & $96,4 \pm 1,0$ & $96,3 \pm 1,7$ & $98,4 \pm 1,0$ & $92,8 \pm 2,0$ & $96,8 \pm 1,2$ & 100 & 100 & $88,2 \pm 1,6$ & 100 & $90,0 \pm 1,5$ & $88,6 \pm 0,2$ \\
\hline 9 & $86,6 \pm 0,5$ & $90,8 \pm 1,8$ & $87,8 \pm 2,6$ & $78,4 \pm 0,2$ & $92,6 \pm 0,8$ & $94,8 \pm 0,5$ & $94,2 \pm 1,3$ & $96,2 \pm 0,9$ & 100 & 100 & $92,2 \pm 0,9$ & $80,2 \pm 1,6$ & $84,3 \pm 0,4$ \\
\hline 10 & $96,6 \pm 2,0$ & $92,4 \pm 2,2$ & $92,8 \pm 2,0$ & $86,4 \pm 1,0$ & $88,4 \pm 2,6$ & $86,2 \pm 0,2$ & $98,0 \pm 1,0$ & 100 & $98,4 \pm 0,4$ & 100 & $91,8 \pm 0,6$ & $79,8 \pm 0,2$ & $92,0 \pm 1,5$ \\
\hline 11 & $78,9 \pm 1,3$ & $89,3 \pm 3,0$ & $92,5 \pm 0,5$ & $89,9 \pm 1,1$ & $94,4 \pm 2,4$ & 100 & $79,0 \pm 2,0$ & $88,3 \pm 0,4$ & $90,2 \pm 2,0$ & $97,2 \pm 0,4$ & 100 & $81,6 \pm 0,2$ & $85,5 \pm 0,5$ \\
\hline 12 & $80,3 \pm 2,2$ & $93,5 \pm 0,5$ & $88,5 \pm 2,4$ & $94,2 \pm 2,0$ & $89,6 \pm 0,5$ & $88,5 \pm 0,6$ & $84,2 \pm 2,1$ & $92,3 \pm 1,3$ & 100 & $91,8 \pm 0,8$ & $88,3 \pm 0,9$ & 100 & $89,9 \pm 0,5$ \\
\hline 13 & $86,2 \pm 1,9$ & $84,2 \pm 0,2$ & $87,3 \pm 2,7$ & $98,8 \pm 0,8$ & $88,1 \pm 1,9$ & $78,6 \pm 1,0$ & $88,4 \pm 2,0$ & $87,2 \pm 2,0$ & $94,3 \pm 1,6$ & $94,3 \pm 0,5$ & $91,1 \pm 1,1$ & $95,1 \pm 0,6$ & 100 \\
\hline
\end{tabular}


лактозу и галактозу. Вариабельность признака наблюдали в отношении маннозы и маннита, о чем свидетельствуют и результаты, полученные другими исследователями (20-22).

Для идентификации изолятов A. paragallinarum важное значение имело определение антигенного родства в реакции агглютинации на стекле. В результате исследований антигенное родство референтного штамма и выделенных изолятов установлено не было. Все изоляты A. paragallinarum представляли собой гомологичную группу за исключением №№ 6, 7, 10 и 11. Антигены этих изолятов проявляли лишь одностороннее родство с испытуемыми сыворотками, что не позволило сделать вывод об их принадлежности к разным серологическим группам.

Мы также определили антигенное родство изолятов A. paragallinarum в реакции торможения гемагглютинации (табл. 2) в порядке сравнении результатов серотипирования по агглютинации и гемагглютинации (23). Полученные нами данные свидетельствуют о том, что все изученные изоляты представляли собой однородную группу по гемагглютинину. Минимальное значение двустороннего родства (R) составило 78,4 \%. То есть можно предположить, что все изоляты принадлежали к одной серогруппе и одному серотипу.

Учитывая полученные результаты сходства изолятов по ростовым, антигенным и морфологическим свойствам, для дальнейшей работы отобрали 10 наиболее перспективных изолятов, которые сохраняли стабильность гемагглютинирующих, антигенных, вирулентных и иммуногенных свойств в течение 20 последовательных пассажей.

Возможность определения серогрупповой принадлежности $A$. paragallinarum в ПЦР ранее показали R. Sakamoto с coaвт. (16) и V.V. Patil с соавт. (17). В нашей работе гомогенность серогруппы изолятов, выделенных от птиц с респираторной патологией, была подтверждена с помощью мультиплексной ПЦР-РВ (рис. 1). У всех изолятов ампликоны образцов имели размер 1000-1100 п.н., что соответствовало продукту ПЦР-амплификации, характерному для $A$. paragallinarum серогруппы В.

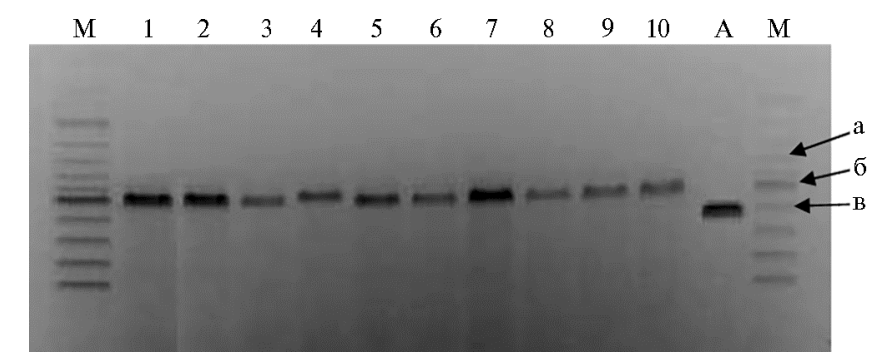

Рис. 1. Электрофореграмма продуктов ПЦР-амплификации при определении антигенной принадлежности референтного штамма Avibacterium paragallinarum № 29545 АТСС и изолятов A. paragallinarum, полученных от кур с респираторной патологией: а - серогруппа С (15001600 п.н.), б - серогруппа В (1000-1100 п.н.), серогруппа А (800 п.н.); 1-10 - образцы изолятов №№ 1-10, А - штамм A. paragallinarum № 29545, М - маркер длины фрагментов ДНК (ЗАО «Евроген», Россия).

На основании изученных морфологических, биохимических и антигенных характеристик три изолята A. paragallinarum были депонированы в Государственную коллекцию штаммов микроорганизмов ФГБУ ВНИИЗЖ: изолят № 4 - как штамм № 1818, изолят № 8 - как штамм № 5111 и изолят № 12 - как штамм № 1116.

На следующем этапе мы сформировали базу данных масс-спектров 
контрольно-производственных штаммов A. paragallinarum № 5111, № 1818 и № 1116 и референтного штамма АТСС 29545, которые предполагается использовать в дальнейшем для автоматизированной идентификации и профилирования представителей этого вида на основе сходства/различия масс-спектрометрических характеристик.

Для изолятов и штаммов A. paragallinarum были построены белковые профили (рис. 2) и сформированы масс-листы, по которым стало возможным определение характерных пиков (табл. 3). В соответствии с протоколом, изложенным J.H.K Chen с соавт. (24) и N. Takeuchi с соавт. (25), в процессе идентификации штаммов и изолятов A. paragallinarum мы сравнивали такие параметры, как положение пиков, их частота и интенсивность.
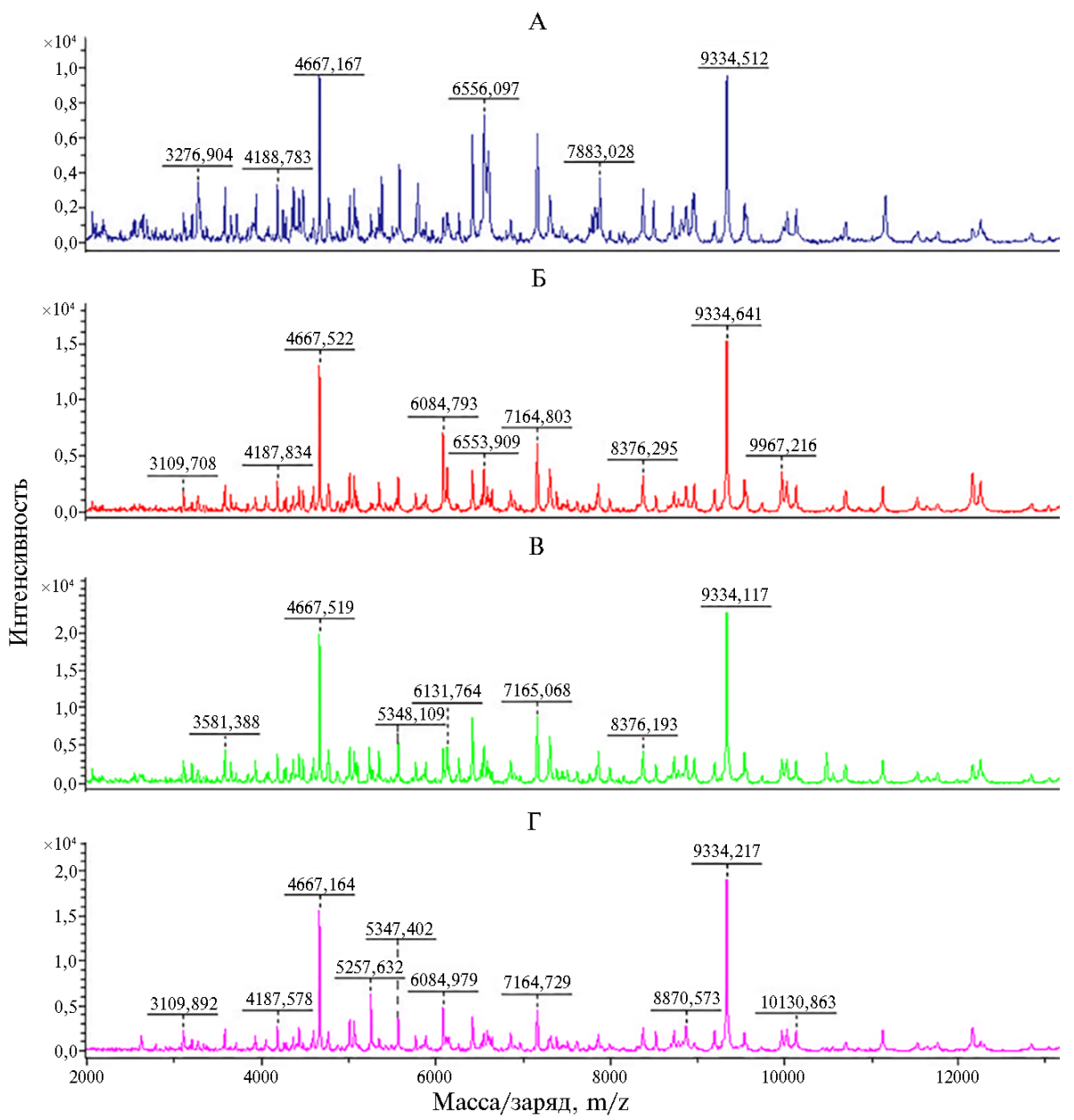

Рис. 2 Масс-спектры индивидуальных колоний референтного штамма Avibacterium paragallinarum № 29545 АТСС (А) и контрольно-производственных штаммов №№ 1818 (Б), 1116 (В), 5111 (Г), которые были получены на основе изолятов A. paragallinarum, выделенных от кур с респираторной патологией (пики $\mathrm{m} / \mathrm{z} 4667$ и 9334 были общими для всех штаммов A. paragallinarum).

При анализе полученных спектров было установлено, что они находились в диапазоне $\mathrm{m} / \mathrm{z}$ 2000-10000. Для всех штаммов и изолятов A. paragallinarum общими оказались пики $\mathrm{m} / \mathrm{z} 4667$ и 9334. Уникальная особенность программы MALDI Biotyper - возможность пополнения персональной базы новыми спектрами и проведение анализа масс-спект- 
ров, основанного на сравнении полученных белковых профилей с персональной библиотекой референтных спектров. В результате проведенной работы был создан соответствующий подраздел этой базы данных масс-спектров (на уровне вида $A$. paragallinarum), который в дальнейшем можно использовать для идентификации штаммов и изолятов возбудителя инфекционного ринита кур.

3. Протеомическая характеристика штаммов и изолятов Avibacterium paragallinarum, полученных от кур с респираторной патологией

\begin{tabular}{|c|c|c|c|}
\hline Пики m/z & $\begin{array}{l}\text { Показатель } \\
\text { интенсивности S/N }\end{array}$ & $\begin{array}{l}\text { Встречаемость } \\
\text { пика, \% }\end{array}$ & $\begin{array}{l}\text { Наличие пика у штамма } A \text {. paragallinarum } \\
\text { АТСС } 29545 / \text { соотношение S/N }\end{array}$ \\
\hline $2067-2069$ & $4,4-12,4$ & 43 & - \\
\hline $3109-3111$ & $4,1-5,9$ & 36 & - \\
\hline $3208-3210$ & $4,0-8,6$ & 57 & - \\
\hline $3580-3582$ & $4,0-10,1$ & 71 & $+/ 6,2$ \\
\hline $3930-3932$ & $4,3-9,5$ & 14 & - \\
\hline $4186-4188$ & $4,3-8,1$ & 71 & $+/ 6,6$ \\
\hline $4278-4280$ & $4,6-11,7$ & 36 & - \\
\hline $4433-4435$ & $4,4-7,6$ & 57 & $+/ 5,1$ \\
\hline $4480-4482$ & $4,0-7,9$ & 28 & $+/ 6,1$ \\
\hline 4667 & $9,2-39,7$ & 100 & $+/ 19,3$ \\
\hline $4768-4770$ & $4,2-7,6$ & 57 & $+/ 5,2$ \\
\hline 5011 & $4,9-8,8$ & 86 & $+/ 5,7$ \\
\hline 5065 & $4,8-9,6$ & 78 & $+/ 6,4$ \\
\hline $5098-5060$ & $8,7-16,7$ & 57 & - \\
\hline $5347-5349$ & $4,3-5,3$ & 28 & $+/ 4,2$ \\
\hline $5542-5543$ & $5,1-7,7$ & 21 & - \\
\hline $5567-5569$ & $4,4-7,7$ & 64 & - \\
\hline 6084 & $5,0-14,7$ & 78 & - \\
\hline $6261-6263$ & $4,2-17,7$ & 50 & - \\
\hline 6420 & $6,4-24.7$ & 86 & $+/ 13,9$ \\
\hline $6552-6553$ & $4,3-16,8$ & 36 & $+/ 16,8$ \\
\hline $6643-6645$ & $4,3-5,7$ & 21 & - \\
\hline $6855-6857$ & $4,3-5,1$ & 28 & - \\
\hline 7164 & $10,7-22,7$ & 93 & $+/ 15,6$ \\
\hline $7308-7310$ & $7,6-11,2$ & 50 & - \\
\hline 7864-7866 & $5,9-12,2$ & 57 & - \\
\hline $8373-8375$ & $6,9-10,7$ & 64 & - \\
\hline $8522-8524$ & $4,4-6,7$ & 28 & - \\
\hline 9317-9319 & $10,0-10,7$ & 14 & - \\
\hline 9334 & $24,0-62,3$ & 100 & $+/ 33,2$ \\
\hline 9536-9538 & $7,2-12,3$ & 71 & - \\
\hline 9964-9965 & $10,1-13,0$ & 50 & - \\
\hline
\end{tabular}

Таким образом, по биохимическим свойствам изоляты Avibacterium paragallinarum, выделенные от кур с респираторной патологией при обследовании хозяйств в ряде областей (Россия, Белоруссия), представляют собой неоднородную группу, в то время как результаты определения двустороннего родства в реакции торможения гемагглютинации указывают на принадлежность всех изученных изолятов не только к одной серогруппе, но и к одному серотипу. Гомология изолятов на уровне группы была подтверждена методом типирующей мультиплексной ПЦР. При исследовании их протеомических свойств мы выявили характерные пики $\mathrm{m} / \mathrm{z}$ 4768-4770 и 5347-5349, аналогичные наблюдаемым у референтного штамма A. paragallinarum АТСС № 29545, который включен в базу данных массспектрометра. В результате имеющаяся база данных была расширена новыми спектрами и профилями, полученными для тестируемых штаммов, что повысило степень достоверности видовой идентификации. На основании изученных биохимических, антигенных и протеомных характеристик три изолята $A$. paragallinarum депонированы в Государственную коллекцию штаммов микроорганизмов ФГБУ Федеральный центр охраны здоровья 
Авторы благодарят заведующего референтной лаборатории вирусных болезней птии ФГБУ ВНИИЗЖ Д.Б. Андрейчука за помощь в антигенном типировании Avibacterium paragallinarum с использованием мультиплексной полимеразной цепной реакции (ПЦР) в реальном времени.

\section{ЛИТЕРАТУРА}

1. Рождественская Т.Н., Кононенко Е.В., Емельянова С.А., Яковлев С.С., Теймуразов М.Г., Светоч Э.А., Тазина О.И., Платонов М.Е., Детушев К.В., Хатюшин Ю.И. Гемофилез птиц. Птица и птицепродукты, 2016, 4: 50-53.

2. Chukiatsiri K., Chotinun S., Chansiripornchai N. An outbreak of Avibacterium paragallinarum serovar B in a Thai layer farm. The Thai Journal of Veterinary Medicine, 2010, 40(4): 441-444.

3. Poernomo S., Sutarma S., Rafiee M., Blackall P.J. Characterisation of isolates of Haemophilus para-gallinarum from Indonesia. Australian Veterinary Journal, 2000, 78(11): 759-762 (doi: 10.1111/j.1751-0813.2000.tb10447.x).

4. Akhter S., Ali M., Das P.M., Hossain M.M. Isolation and identification of Avibacterium paragallinarum the causal agent of infectious coryza (IC) from layer chickens in Bangladesh. Journal of the Bangladesh Agricultural University, 2014, 11: 87-96 (doi: 10.3329/jbau.v11i1.18218).

5. Vargas E.S., Terzolo H.R. Haemophillus paragallinarum: etiology of infectious coryza. Veterinaria México, 2004, 35(3): 245-259.

6. Byarugaba D.K., Minga U.M., Gwakisa P.S., Katunguka-Rwakishaya E., Bisgaard M., Olsen J.E. Virulence characterization of Avibacterium paragallinarum isolates from Uganda. Avian Pathology, 2007, 36(1): 35-42 (doi: 10.1080/03079450601102947).

7. Лизун Р.П. Диагностика гемофилеза кур (обзор). Экология и животный мир, 2016, 1: 42-49.

8. Lau A.F., Drake S.K., Calhoun L.B., Henderson C.M., Zelazny A.M. Development of a clinically comprehensive database and a simple procedure for identification of molds from solid media by matrix-assisted laser desorption ionization-time of flight mass spectrometry. Journal of Clinical Microbiology, 2013, 51(3): 828-834 (doi: 10.1128/JCM.02852-12).

9. Clark A.E., Kaleta E.J., Arora A., Wolk D.M. Matrix-assisted laser desorption ionization-time of flight mass spectrometry: a fundamental shift in the routine practice of clinical microbiology. Clinical Microbiology Reviews, 2013, 26(3): 547-603 (doi: 10.1128/CMR.00072-12).

10. Chalupová J., Raus M., Sedlářová M., Šebela M. Identification of fungal microorganisms by MALDI-TOF mass spectrometry. Biotechnology Advances, 2014, 32(1): 230-241 (doi: 10.1016/j.biotechadv.2013.11.002).

11. Alshawa K., Beretti J.-L., Lacroix C., Feuihade M., Dauphin B., Quesne G., Hassouni N., Hassif X., Bougnoux M.-E. Successful identification of clinical dermatophyte and Neoscytalidium species by matrix-assisted laser desorption ionization-time of flight mass spectrometry. Journal of Clinical Microbiology, 2012, 50(7): 2277-2281 (doi: 10.1128/JCM.06634-11).

12. Методы общей бактериологии. Том 1 /Под ред. Ф. Герхардта, Р. Мюррей, Р.Н. Костилова, Е.В. Нестер, В.А. Вуд, Н.Р. Криег, Ф.Г. Бриггс; пер. с англ. под ред. Е.Н. Кондратьевой, Л.В. Калакуцкого. М., 1983.

13. Page L.A. Haemophilus infections in chickens. I. Characteristics of 12 Haemophilus isolates recovered from diseased chickens. American Journal of Veterinary Research, 1962, 23: 85-95.

14. Blackall P.J., Eaves L.E. Serological classification of Australian and South African isolates of Haemophilus paragallinarum. Australian Veterinary Journal, 1988, 65(11): 362-363 (doi: 10.1111/j.1751-0813.1988.tb14271.x).

15. Archetti I., Horsfall F.L. Persistent antigenic variation of influenza A virus after incomplete neutralization in ovo with heterologous immune serum. The Journal of Experimental Medicine, 1950, 92(5): 441-462 (doi: 10.1084/jem.92.5.441).

16. Sakamoto R., Kino Y., Sakaguchi M. Development of a multiplex PCR and PCR-RFLP method for serotyping of Avibacterium paragallinarum. The Journal of Veterinary Medical Science, 2012, 74(2): 271-273 (doi: 10.1292/jvms.11-0319).

17. Patil V.V., Mishra D., Mane D.V. 16S ribosomal RNA sequencing and molecular serotyping of Avibacterium paragallinarum isolated from Indian field conditions. Veterinary World, 2017, 10(8): 1004-1007 (doi: 10.14202/vetworld.2017.1004-1007).

18. Kumar A., Rawat M., Verma R. Studies on absolute requirement of NAD and reduced oxygen ten-sion for growth of field isolates of Avibacterium paragallinarum of poultry origin. Indian Journal Poultry Science, 2012, 47(1): 90-92.

19. Banani M., Pourbakhsh S.A., Khaki P., Goudarzi H., Moazeni-Joula G., Ghodsian N. Isolation, identification and antibiotic sensitivity of Haemophilus paragallinarum isolates from commercial layer flocks affected by infectious coryza. Pajouhesh-Va-Sazandegi, 2007, 19(1): 128-135. 
20. Patil V.V., Mishra D.N, Mane D.V. Isolation, characterization and serological study of Avibacterium paragallinarum field isolates from Indian poultry. Journal of Animal and Poultry Sciences, 2016, 5(1): 13-20.

21. Kaur J., Sharma N.S., Gupta K., Singh A. Epidemiological studies on infectious coryza in chickens in Northern India. Indian Journal of Animal Sciences, 2004, 74(5): 462-465.

22. Теймуразов М.Г., Платонов М.Е., Тазина О.И., Манин Т.Б. Биологические свойства штаммов Avibacterium paragallinarum и Gallybacterium anatis, выделенных в Российской Федерации в 2015 г. Ветеринария, 2016, 6: 26-29.

23. Eaves L.E., Rogers D.G., Blackall P.J. Comparison of hemagglutinin and agglutinin schemes for the serological classification of Haemophilus paragallinarum and proposal of a new hemagglutinin serovar. Journal of Clinical Microbiology, 1989, 27(7): 1510-1513 (doi: 10.1128/jcm.27.7.1510-1513.1989).

24. Chen J.H.K., Cheng V.C.C., Wong C.-P., Wong S.C.Y., Yam W.-C., Yuen K.-Y. Rapid differentiation of Haemophilus influenzae and Haemophilus haemolyticus by use of matrix-assisted laser desorption ionization-time of flight mass spectrometry with ClinProTools mass spectrum analysis. Journal of Clinical Microbiology, 2017, 55(9): 2679-2685 (doi: 10.1128/JCM.00267-17).

25. Takeuchi N., Segawa S., Ishiwada N., Ohkusu M., Tsuchida S., Satoh M., Matsushita K., Nomura F. Capsular serotyping of Haemophilus influenzae by using matrix-associated laserdesorption ionization-time of flight massspectrometry. Journal of Infection and Chemotherapy, 2018, 24(7): 510-514 (doi: 10.1016/j.jiac.2018.02.007).

ФГБУ Федеральный центр охраны здоровья жиивотных, 600901 Россия, г. Владимир, мкр. Юрьевец, ФГБУ ВНИИзЖ, e-mail: potehin@arriah.ru, shadrova@arriah.ru,pruntova@arriah.ru $\bowtie$, Поступила в редакцию rusaleev@arriah.ru,evgrafova@arriah.ru

\section{BIOCHEMICAL, ANTIGENIC AND PROTEOMIC PROPERTIES OF ISOLATES AND STRAINS OF THE CAUSATIVE AGENT OF CHICKEN INFECTIOUS CORYZA Avibacterium paragallinarum (Biberstein and White 1969) Blackall et al. 2005}

\section{A.V. Potehin, N.B. Shadrova, O.V. Pruntova, V.S. Rusaleev, Val.A. Evgrafova}

Federal Center for Animal Health Control, FGBU VNIIZZh, mkr. Yurievets, Vladimir, 600901 Russia, e-mail potehin@arriah.ru, shadrova@arriah.ru, pruntova@arriah.ru (corresponding author $₫$ ), rusaleev@arriah.ru, evgrafova@arriah.ru

ORCID:

Potehin A.V. orcid.org/0000-0002-3529-4809

Shadrova N.B. orcid.org/0000-0001-7510-1269

Rusaleev V.S. orcid.org/0000-0002-4972-6326

Pruntova O.V. orcid.org/0000-0003-3143-7339

Evgrafova Val.A. orcid.org/0000-0003-3053-6976

The authors declare no conflict of interests

Acknowledgements:

We are thankful to D.B. Andreychuk, Head of Reference Laboratory for Viral Avian Diseases, ARRIAH, for the assistance in Avibacterium paragallinarum antigenic typing using multiplex-PCR.

Received September 4, 2019

doi: 10.15389/agrobiology.2020.4.804eng

\section{Abstract}

Infectious coryza (haemophilus infection) of chickens is a disease reported in many countries of the world. In the Russian Federation, there is no information both about the extent of the disease spread across the poultry farms and about the serotype diversity of the agent circulating in the country. The paper for the first time demonstrates biochemical properties and specifies antigenic relatedness of new Avibacterim paragallinarum isolates recovered from chickens with respiratory signs in Russia and in Belarus. The paper also shows results of creation of the Avibacterim paragallinarum subsection in the database of tested microorganisms' mass-spectra which can be used as reference ones for the identification and protein profiling of the infectious coryza agent strains and isolates. The work aimed to determine biochemical and antigenic properties of $A$. paragallinarum isolates and to produce the species-specific mass-spectra as a tool for Avibacterim paragallinarum species identification and intraspecies differentiation. A. paragallinarum No. 29545 ATCC (serotype A1) form the collection of the Federal Centre for Animal Health (ARRIAH) served as a reference strain. Thirteen A. paragallinarum isolates were used in the study. The isolates were recovered from the pathological material collected from chickens with respiratory pathology (nasal exudates, contents of infraorbital sinus and conjunctival sac, lung tissues) in 2015. The isolates were inoculated onto Columbia agar supplemented with $5 \%$ defibrinated sheep blood, together with a streak of Staphylococcus epidermid- 
is. Pure cultures of the agent were grown on the serum agar containing NADP at $20 \mu \mathrm{kg} / \mathrm{cm}^{3}$ and $5 \%$ of horse blood serum. The bacteria were cultured for 24-72 at high $\mathrm{CO}_{2}$ concentration and $37{ }^{\circ} \mathrm{C}$. Bilateral antigenic relatedness of the reference strain ATCC No. 29545 and A. paragallinarum isolates was determined using slide agglutination test (SAT). Hemagglutination activity was assessed using hemagglutination inhibition test (HI). Homogeneity of the tested isolates' serogroup was confirmed by PCR. Amplified 800 bp DNA fragments were indicative of the presence of serogroup A A. paragallinarum genome, 1000-1100 bp of serogroup B, and 1500-1600 bp of serogroup C. A. paragallinarum identification was performed using MALDI Autoflex III Biotyper mass-spectrometer (Bruker Daltonik GmbH, Germany). The resulted mass-spectra were recorded, processed and analyzed using FlexControl 3.4 software (Bruker Daltonik Gmb», Germany) according to MALDIBiotyper 2.0. UserManual, Version 2.0 SR1, Germany, 2008. Testing of biochemical properties indicated that all 13 isolates of A. paragallinarum form a diverse group. The A. paragallinarum isolates' growth absolutely depended upon presence of blood serum in the culture medium. Saccharolytic activity of the $A$. paragallinarum isolates also varied. All isolates and the reference strain can utilize glucose and sucrose, but not lactose, trehalose and galactose. The property also varied for mannitol and mannose. As for antigenic properties, all tested isolates belonged to the same serogroup B that was also confirmed by real-time polymerase chain reaction method. Examination of proteomic properties of A. paragallinarum isolates revealed typical MS peaks, m/z 4768-4770 and 5347-5349, that were similar to those for the reference strain A. paragallinarum ATCC No. 29545. Protein profile mass-spectra were entered into MALDI Autoflex III Biotyper database to improve the reliability of A. paragallinarum species identification. Basing on the examined biochemical, antigenic and proteomic properties, three $A$. paragallinarum isolates were deposited ineщ the strain collection of the Federal Centre for Animal Health (ARRIAH) as A. paragallinarum strain No. 1818, A. paragallinarum strain No. 5111, and A. paragallinarum strain No. 1116.

Keywords: strain, isolate, Avibacterium paragallinarum, identification, biochemical characterization, antigenic properties, proteomic properties, mass spectrometry, agglutination test, hemagglutination inhibition assay. 